\title{
Pengaruh Pupuk Mikoriza Terhadap Pertumbuhan Cabai Rawit (Capsicum frutescens) di Tanah Pasir
}

\author{
V. Adetya, S. Nurhatika, dan A. Muhibuddin \\ Departemen Biologi, Fakultas Ilmu Alam, Institut Teknologi Sepuluh Nopember (ITS) \\ Departemen Hama dan Penyakit Tumbuhan, Fakultas Pertanian, Universitas Brawijaya, Malang \\ e-mail: nurhatika@bio.its.ac.id
}

\begin{abstract}
Abstrak - Salah satu upaya pemanfaatan lahan pasir di Indonesia adalah budidaya cabai, namun rendahnya unsur hara dalam pasir merupakan kendala utama. Aplikasi mikoriza arbuskula adalah salah satu solusi alternatif untuk meningkatkan produktivitas tanaman di tanah pasir. Tujuan penelitian ini untuk mengetahui pertumbuhan cabai rawit (Capsicum frutescens) yang ditanam di tanah pasir dengan penambahan pupuk mikoriza berbeda dosis yaitu $0 \mathrm{~g}, 2 \mathrm{~g}, 4 \mathrm{~g}, 6 \mathrm{~g}$ dan $10 \mathrm{~g}$ serta kontrol positif menggunakan tanah taman. Adanya pengaruh dosis mikoriza terlihat dari parameter pengamatan meliputi tinggi, luas daun dan berat kering tanaman. Persentase akar terinfeksi dan jumlah spora juga diamati untuk mengetahui proses infeksi mikoriza pada tanaman cabai rawit. Hasil penelitian menunjukkan bahwa budidaya cabai rawit di tanah pasir dengan penambahan $6 \mathrm{~g}$ mikoriza sudah mampu meningkatkan hasil pertumbuhan namun belum bisa disamakan dengan pertumbuhan $C$. frutescens yang ditanam di tanah taman. Infeksi akar dan jumlah spora paling banyak terdapat pada cabai rawit dengan pemberian $10 \mathrm{~g}$ mikoriza.
\end{abstract}

Kata Kunci-Capsicum frutescens, mikoriza, tanah pasir.

\section{PENDAHULUAN}

$\mathrm{I}^{\mathrm{s}+\mathrm{s}^{2}}$ NDONESIA memiliki panjang garis pantai mencapai $106.000 \mathrm{~km}$ dengan potensi luas lahan 1.060.000 ha, secara umum termasuk lahan marginal berpasir, namun belum dikelola dengan baik. Salah satu upaya pemanfaatan lahan pasir adalah melalui usaha tani cabai. Selain berumur pendek, cabai mempunyai nilai ekonomi tinggi dan peluang pasar yang baik. Sifat lahan pasir yaitu kurang kuat menahan air, permeabilitas dan drainase sangat cepat, serta miskin hara merupakan kendala utama budidaya cabai rawit di tanah pasir.

Upaya dalam mengatasi masalah tersebut diperlukan teknik pengelolaan tanah untuk menstabilkan kandungan organik tanah yang berpengaruh terhadap karakteristik tanah dalam menahan kapasitas air, unsur hara tanah serta mengoptimalkan pertumbuhan tanaman [1]. Pengelolaan tanah dengan meningkatkan peran mikoriza arbuskular (AM) indigenuous di tanah berpasir adalah salah satu solusi alternatif terbaik untuk meningkatkan produktivitas tanaman [2].

Mikoriza Vesikular Arbuskular (MVA) adalah salah satu jenis cendawan tanah, yang keberadaannya dalam tanah sangat mempunyai manfaat. Hal ini karena mikoriza berperan dalam memperbaiki kualitas tanah melalui peningkatan agregat dan koloid tanah serta dapat membantu tanaman dalam meningkatkan penyerapan $\mathrm{N}, \mathrm{P}, \mathrm{K}, \mathrm{Ca}$ dan nutrisi mikro lainnya. Selain itu hifa eksternal mikoriza akan meningkatkan ketahanan tanaman terhadap kekeringan, melindungi akar tanaman dari infeksi patogen tanah, merangsang aktivitas mikroorganisme lain yang menguntungkan dan memperbaiki tekstur dan struktur tanah [2]. Penelitian [3] menunjukkan bahwa pemberian jenis dan dosis cendawan mikoriza arbuskular berpengaruh terhadap tinggi, biomassa akar dan kandungan $\mathrm{P}$ tanaman cabai merah (Capsicum annuum L.) yang ditanam di tanah ultisol.

Tujuan dari penelitian ini untuk mengetahui pengaruh dosis pemberian pupuk mikoriza terhadap pertumbuhan cabai rawit (Capsicum frutescens) yang ditumbuhkan pada media tanah pasir.

\section{METODE PENELITIAN}

\section{A. Waktu dan Tempat Penelitian}

Penelitian dilakukan pada bulan Februari sampai dengan Juni 2018 di Laboratorium Biosains dan Teknologi Tumbuhan Departemen Biologi Fakultas Ilmu Alam dan Green House Urban Farming Institut Teknologi Sepuluh Nopember.

\section{B. Penyiapan Media Tanam}

Media tanam berupa pasir sungai jenis pasir Lamongan yang diperoleh dari toko bangunan di Surabaya dan tanah taman yang diperoleh dari toko bunga di Surabaya. Diperlukan $3 \mathrm{~kg}$ media tanam untuk setiap polybag. Sterilisasi pasir dilakukan dengan pemberian formalin $5 \%$. Perbandingannya setiap $3 \mathrm{~kg}$ media tanam dicampur dengan $75 \mathrm{ml}$ formalin 5\%. Kemudian ditutup dengan plastik selama 7 hari, setelah itu dibuka dan dihawakan selama 3 hari.

\section{Penyemaian Benih dan Penanaman Bibit}

Penyemaian benih dilakukan dengan mempersiapkan media semai yaitu tanah dicampus kompos dengan perbandingan 1:1 yang sebelumnya telah disterilisasi menggunakan autoklaf. Setelah benih berkecambah hingga muncul 4 helai daun, dipindah pada media tanam sesungguhnya. Media tanam yang telah disterilisasi sebanyak $3 \mathrm{~kg}$ dimasukkan ke dalam polybag. Dosis pupuk mikoriza yang diberikan adalah $2 \mathrm{~g}, 4 \mathrm{~g}$, 
$6 \mathrm{~g}, 8 \mathrm{~g}$ dan $10 \mathrm{~g}$. Inokulasi mikoriza dilakukan dengan menggunakan sistem lapisan. Media tanam dilubangi dengan ketebalan $10 \mathrm{~cm}$, diatasnya diberi pupuk mikoriza sesuai perlakuan, dilapisi dengan media tanam setebal $2 \mathrm{~cm}$, lalu diletakkan bibit cabai diatasnya dan dilapisi kembali dengan media tanam. Tanaman ditumbuhkan di green house selama 14 minggu.

\section{Pengamatan Infeksi Akar}

Perhitungan infeksi akar dilakukan minimal setelah 4 minggu masa penanaman [4]. Untuk menghitung persen infeksi akar perlu dibuat terlebih dahulu preparat akar semi permanen. Persen infeksi mikoriza di hitung dari jumlah akar yang terinfeksi dari 10 potongan akar yang diamati. Akar yang terinfeksi ditandai dengan adanya vesikel atau arbuskula dalam korteks akarnya. Persen infeksi mikoriza dihitung berdasarkan rumus [5].

$$
\% \text { infeksi }=\frac{J A T}{J S P} \times 100 \%
$$

Keterangan:

JAT : jumlah akar yang terinfeksi mikoriza

JSP : jumlah total potongan akar

Metode pewarnaan akar diadaptasi dari [5] dimodifikasi Laboratorium Bioteknologi Hutan Institut Pertanian Bogor. Akar dicuci sampai bersih dengan air mengalir. Pencucian 3 kali biasanya sudah cukup bersih. Rendam akar dalam $\mathrm{KOH}$ 10\% selama 24 jam. Selanjunya dibilas dengan air 3-5 kali, menggunakan penyaring teh sebagai wadah. Akar direndam dalam $\mathrm{HCl} 1 \%$ selama 12 jam. Setelah perendaman dengan $\mathrm{HCl}$ akar tidak perlu dibilas dengan air, namun direndam dalam larutan pewarna Lactofenol Cotton Blue selama 12-18 jam. Setelah itu rendam dalam larutan destaining gliserol selama 30 menit untuk menghilangkan kelebihan larutan pewarna. Akar dipotong sepanjang kurang lebih $1 \mathrm{~cm}$ dan kemudian letakkan berjajar pada gelas objek. Setiap 10 potong akar ditutup dengan sebuah cover slip dan diulangi sebanyak 3 kali [6]. Persen infeksi mikoriza dihitunng dari jumlah akar yang terinfeksi dari 30 potongan akar yang diamati. Pengamatan dilakukan dengan menggunakan mikroskop. Akar yang terinfeksi mikoriza ditandai dengan adanya vesikel atau arbuskula dalam korteks akar tanaman. Mikoriza dikatakan viabel jika mempunyai persentase infeksi sebesar $50 \%$.

\section{E. Pengamatan Jumlah Spora}

Pengamatan jumlah spora menggunakan metode wetsieving and decanting. Prinsip dari metode ini adalah menggunakan saringan metal berbagai ukuran untuk memisahkan spora. Saringan yang lebih kasar $(500-2000 \mu \mathrm{m})$ berfungsi memisahkan bahan-bahan organik dan partikel tanah yang kasar, sedangkan saringan halus $(38-250 \mu)$ berfungsi untuk spora-spora yang berbeda ukuran [7]. Media tanam pasir ditimbang sebanyak 100 gr dimasukkan ke dalam wadah berisi air sebanyak $500 \mathrm{ml}$, diaduk sampai homogen. Umumnya 100 $\mathrm{g}$ tanah adalah jumlah yang terbaik, dapat digunakan pula jumlah sampel yang lebih besar hingga $1 \mathrm{~kg}$ tanah namun harus dipastikan saringan tidak tersumbat. Kemudian didiamkan selama 10 menit sampai partikel-partikel mengendap, suspensinya dituangkan kesaringan tingkat empat dengan diameter lubang berturut-turut dari atas ke bawah adalah 600, 180, 75, 63 dan $38 \mu \mathrm{m}$. Untuk mencegah penyumbatan lubang saringan, dilakukan penyemprotan dengan air bersih ke permukaan saringan. Bahan yang tertinggal di saringan 75, 63 dan $38 \mu \mathrm{m}$ dicuci dengan air bersih dan di tuangkan dalam tabung-tabung sentrifuge sebagai suspensi sampai volume masing-masing $15 \mathrm{ml}$, ditambahkan larutan sukrosa 60\%. Tabung-tabung tersebut dimasukkan dalam sentrifuge. Sentrifugasi dilakukan selama 5 menit dengan kecepatan $2000 \mathrm{rpm}$. Kemudian suspensi diambil dan dituang ke dalam saringan $38 \mu \mathrm{m}$ dan dicuci dengan penyemprotan air bersih. Pada ayakan terakhir $38 \mu \mathrm{m}$ dibersihkan dengan aquades dan dituangkan ke cawan petri, kemudian dilakukan pengamatan spora menggunakan mikroskop stereo [8].

\section{F. Analisis Data}

Penelitian menggunakan Rancangan Acak Lengkap (RAL) satu faktor yaitu dosis mikoriza. Perlakuan yang dilakukan adalah dengan memberikan dosis mikoriza yang berbeda-beda pada tanaman cabai rawit (Capsicum frutescens) yaitu 2, 4, 6, 8 dan $10 \mathrm{~g}$ serta kontrol tanpa mikoriza. Masing-masing perlakuan di ulang sebanyak 5 kali. Parameter pengamatan pada penelitian ini adalah respon morfologi tumbuhan yaitu tinggi tanaman, luas daun dan berat kering.

\section{HASIL DAN DISKUSI}

\section{A. Tinggi Tanaman}

Pengukuran tinggi tanaman dilakukan dari pangkal batang hingga titik tumbuh tertinggi pada minggu ke-14 setelah tanam atau pada saat panen. Hasil pengamatan respon tinggi tanaman C. frutescens terhadap pemberian pupuk mikoriza disajikan pada Gambar 1.

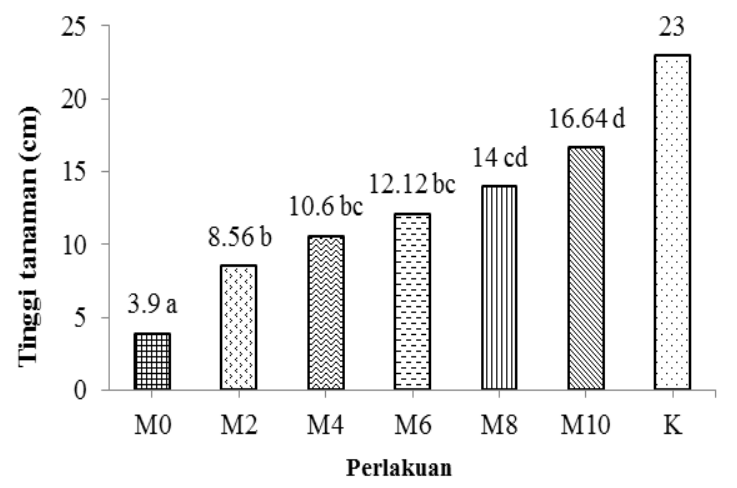

Gambar 1. Tinggi tanaman C. frutescens dengan variasi dosis mikoriza.

Berdasarkan gambar 1 C. frutescens yang diberi pupuk mikoriza sebanyak $10 \mathrm{~g}$ memiliki nilai tertinggi diantara semua tanaman yang ditanam di tanah pasir, namun tidak berbeda nyata dengan perlakuan $8 \mathrm{~g}$. Sedangkan $C$. frutescens dengan tinggi terendah adalah perlakuan $0 \mathrm{~g}$ mikoriza. Tanaman 
kontrol pada penelitian ini memiliki hasil tertinggi dibandingkan tanaman perlakuan. Gambar 1 menunjukkan korelasi positif, semakin banyak mikoriza yang diberikan maka semakin tinggi pula tanaman C. frutescens.

Tinggi tanaman dipengaruhi oleh unsur hara $\mathrm{N}$ maupun $\mathrm{P}$. Unsur $\mathrm{N}$ diperlukan tanaman dalam jumlah terbesar, dan ketersediaannya mempengaruhi biomassa antara akar dan batang. Fosfor dianggap sebagai nutrisi utama untuk pertumbuhan tanaman dan diperlukan untuk mempertahankan produksi dan kualitas tanaman yang optimal. Unsur ini penting untuk pembelahan sel, reproduksi, dan metabolisme tanaman. Selain itu, perannya terkait dengan akuisisi, penyimpanan, dan penggunaan energi [9].

Tanaman kontrol yaitu $C$. frutescens yang ditanam di tanah taman tanpa mikoriza memiliki hasil tertinggi untuk tinggi tanaman dibandingkan perlakuan C. frutescens di tanah pasir dengan penambahan mikoriza. Hal ini disebabkan media tanam yang digunakan juga mempengaruhi pertumbuhan. $C$. frutescens akan bertumbuh dan berproduksi dengan baik apabila ditanam pada lingkungan yang optimum, baik iklim maupun tanah tempat tumbuhnya [10]. Unsur $\mathrm{N}$ total pada tanah taman sebesar $0.11 \%$ dan pada tanah pasir sebesar $0.01 \%$ (Lampiran 2). Besarnya kandungan $\mathrm{N}$ dan $\mathrm{P}$ pada tanah taman dibandingkan tanah pasir menyebabkan tanpa penambahan mikoriza pertumbuhan $C$. frutescens sudah maksimal.

\section{B. Luas Daun}

Pengukuran luas daun $C$. frutescens dilakukan di akhir percobaan pada minggu ke-14. Hasil pengamatan respon luas daun $C$. frutescens terhadap pemberian pupuk mikoriza disajikan pada Gambar 2.

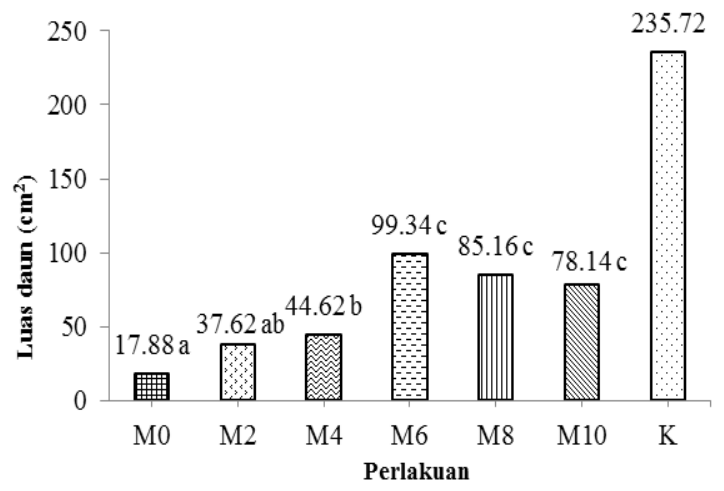

Gambar 2. Luas daun C. frutescens dengan variasi dosis mikoriza

Gambar 2 merupakan grafik rata-rata luas daun dari lima ulangan tiap perlakuan dan analisis statistik yang menunjukkan bahwa semua perlakuan berpengaruh terhadap luas daun $C$. frutescens dengan nilai Sig.< 0.05 (Lampiran 3). Luas daun tertinggi diantara $C$. frutescens yang ditanam di tanah pasir adalah M6 dengan penambahan $6 \mathrm{~g}$ mikoriza memiliki luas $99.34 \mathrm{~cm}^{2}$ namun tidak berbeda nyata dengan perlakuan M8 dan M10.

Luas daun dipengaruhi oleh unsur nitrogen. Nitrogen merupakan unsur penting dalam pembentukan klorofil, protoplasma, protein dan asam-asam nukleat. Unsur ini mempunyai peranan yang penting dalam pertumbuhan dan perkembangan semua jaringan hidup [10]. [11] menyatakan lebih dari 50\% kebutuhan $\mathrm{N}$ tumbuhan dipasok oleh asosiasi mikoriza. Hifa cendawan mikoriza arbuskula mampu memanfaatkan $\mathrm{N}$ anorganik secara efisien dan mentransfernya ke dalam tanah dalam jarak 10-30 cm. Hal ini menunjukkan bahwa cendawan mikoriza arbuskula memungkinkan tanaman inang untuk memiliki akses dan melakukan penyerapan ke sumber $\mathrm{N}$ anorganik. Hifa eksternal intraradisi Glomus mampu menyerap NO3 dan NH4 dan memberikannya ke tanaman inang [12]. Nitrogen menyebabkan penambahan luas daun karena $\mathrm{N}$ tersedia dapat menghasilkan protein yang lebih banyak sehingga daun dapat berkembang lebih lebar. Kekurangan unsur hara $\mathrm{N}$ akan menyebabkan terganggunya pertumbuhan vegetatif yang akhirnya mempengaruhi laju fotosintesis persatuan luas. Berkurangnya laju fotosintesis akan menyebabkan sempitnya daun yang terbentuk [13].

\section{Berat Kering}

Berat kering suatu tanaman menunjukkan hasil produksi tanaman tersebut. Pengukuran berat kering dilakukan saat masa panen atau minggu ke-14 setelah tanam. Analisis satitistik ANOVA menunjukkan bahwa pemberian mikoriza berpengaruh (Sig.<0.05) (Lampiran 4) terhadap berat kering tanaman. Hasil pengamatan berat kering $C$. frutescens dan hasill analisisnya disajikan pada Gambar 3.

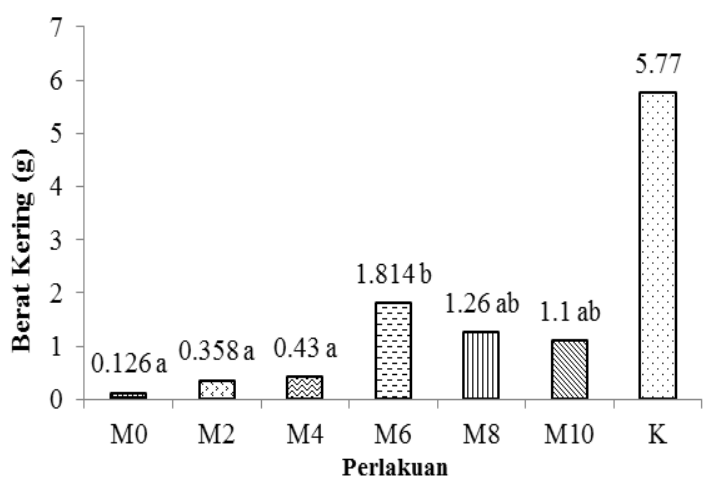

Gambar 3. Berat kering C. frutescens dengan variasi dosis mikoriza

Gambar 3 menunjukkan rata-rat berat kering dan hasil uji Duncan bahwa perlakuan M6 memiliki nilai tertinggi dibanding $C$. frutescens yang ditanam di tanah pasir dengan nilai rata berat kering sebesar $1.814 \mathrm{~g}$, yang berbeda nyata dengan M0, M2 dan M4 namun tidak berbeda nyata dengan M8 dan M10. Perlakuan M6 merupakan $C$. frutescens dengan pemberian $6 \mathrm{~g}$ pupuk mikoriza.

Peningkatan berat kering tanaman dipengaruhi oleh pertumbuhan vegetatif tanaman itu sendiri seperti tinggi tanaman dan luas daun. C. frutescens di tanah pasir yang diberi pupuk mikoriza memperlihatkan pertumbuhan yang lebih baik dibandingkan $C$. frutescens tanpa mikoiza dengan media yang sama. Adanya pengaruh pemberian pupuk mikoriza terhadap berat kering tanaman sejalan dengan penelitian [14] bahwa mikoriza mampu meningkatkan bobot kering tanaman padi sebesar dua kali lipat dibandingkan padi tanpa mikoriza. 


\section{Infeksi Pada Akar}

Hasil infeksi mikoriza pada akar tanaman $C$. frutescens pada minggu ke-14 disajikan pada Gambar 4.

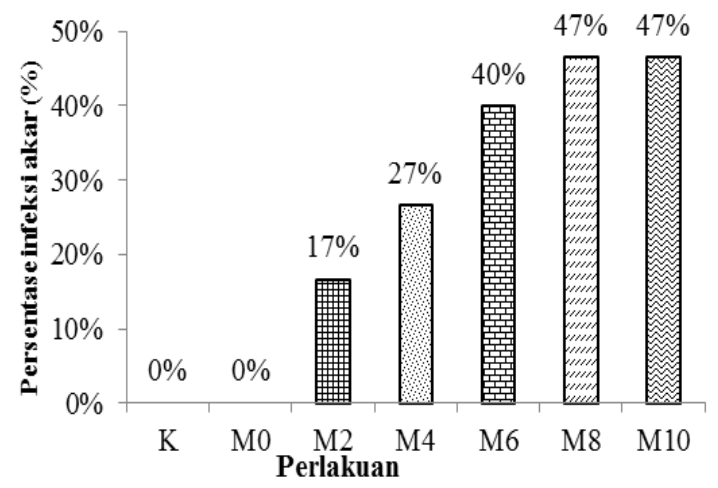

Gambar 4. Infeksi pada akar C. frutescens

Hasil pengamatan menunjukkan pada perlakuan Kontrol dan M0 tanpa pemberian pupuk mikoriza, tidak terjjadi infeksi pada akar. Persentase infeksi mikoriza pada $C$. frutescens. Perlakuan M2 yang diberi pupuk mikoriza $2 \mathrm{~g}$ memiliki infeksi sebesar $17 \%$ dan persentase infeksi semakin besar seiring bertambahnya dosis yang diberikan. Persentase tertinggi pada perlakuan M8 dan M10 yaitu sebesar 47\%. Meningkatnya persentase infeksi karena semakin meningkat pula pupuk mikoriza yang ditambahkan kedalam media tanam, sehingga menyebabkan semakin meningkat pula infeksi yang terjadi. Berikut merupakan hasil pengamatan pada akar.

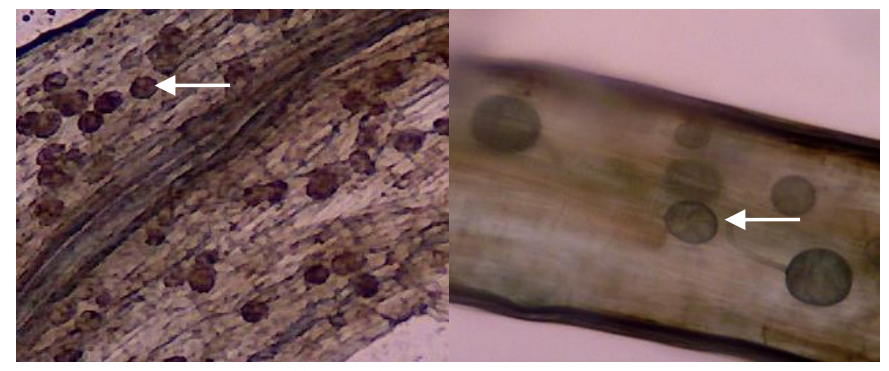

Gambar 5. Spora dan vesikel pada akar (perbesaran 100x)

Berdasarkan pengamatan yang telah dilakukan, pada gambar 5 terdapat spora, hifa, vesikel dan arbuskula. Keadaan tersebut merupakan tanda bahwa mikoriza telah menginfeksi bagian dari akar tanaman. Menurut pendapat [15] menyatakan bahwa mikoriza merupakan jamur yang hidup secara bersimbiosis dengan perakaran tanaman. Berdasarkan pendapat [16] yang menyatakan bahwa semakin banyak jumlah inokulum CMA yang digunakan akan semakin tinggi kolonisasi akar oleh CMA sehingga serapan hara dan air juga akan meningkat [17] Semua jenis tanah mempunyai respon terhadap peningkatan dosis mikoriza dimana secara umum pemberian mikoriza dapat meningkatkan persentase infeksi mikoriza pada akar tanaman jika dibandingkan tanpa pemberian mikoriza. [6] dengan adanya mikoriza perakaran lebih mudah berkembang dan memanjang karena mikoriza dapat mengemburkan tanah disekitar perakaran tanaman sehingga akar tanaman akan leluasa untuk berkembang.

\section{E. Jumlah Spora Dalam Tanah}

Perhitungan jumlah spora dilakukan dengan isolasi media tanam yang dilanjutkan dengan penyaringan basah bertingkat dan pengamatan mikroskopis. Berikut disajikan (Gambar 6) hasil perhitungan jumlah spora pada media tanam pada minggu ke-14.

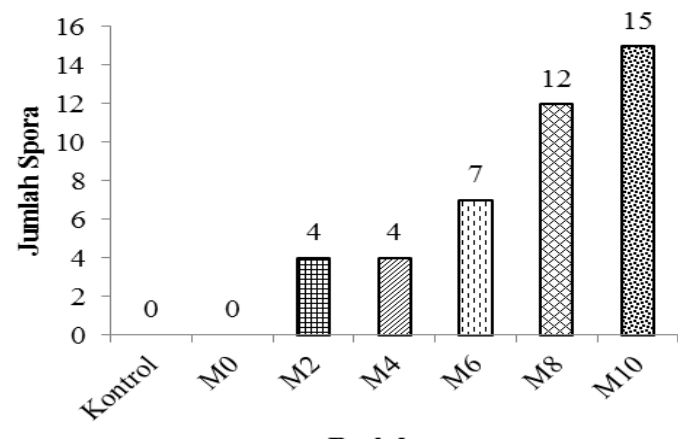

Gambar 5. Jumlah spora dalam tanah

Jumlah spora terbanyak pada perlakuan M8 dan M10 dengan jumlah 7 spora. Sedangkan perlakuan M6 berjumlah 5 spora, dan M4 berjumlah 2 spora. Perlakuan M2 dimana ditambahkan $2 \mathrm{~g}$ mikoriza kedalam media tanam tidak ditemukan spora. Pada Kontrol dan M0 juga tidak ditemukan spora karena dalam perlakuannya tidak ada penambahan pupuk mikoriza. Grafik menunjukkan tren kenaikan jumlah spora terhadap dosis mikoriza. Semakin banyak mikoriza yang ditambahkan ke media tanam, spora yang ditemukan juga makin banyak. Hal tersebut diduga karena dosis inokulum spora CMA yang berbeda mempengaruhi perkembangan jumlah spora pada tanah.

Berikut merupakan hasil pengamatan spora disajikan oleh gambar 6.

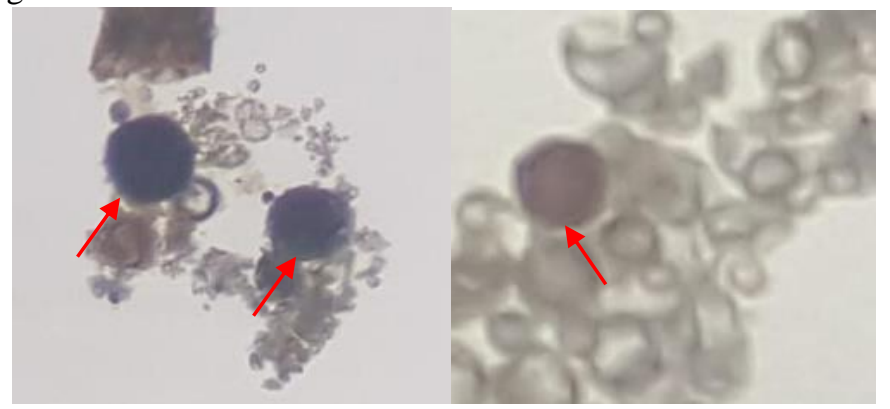

Gambar 6. Spora yang ditemukan pada tanah (perbesaran 100x)

[6] mengatakan bahwa keberadaan mikoriza dipengaruhi oleh beberapa faktor lingkungan seperti cahaya, suhu, kandungan air tanah, $\mathrm{pH}$ tanah, bahan organik serta logam berat dan unsur lainnya. Beberapa penelitian juga menunjukkan bahwa spora mikoriza dipengaruhi oleh karakteristik tanah (Muhibuddin, 2008). Jenis Glomeraceae lebih dominan pada tanah berliat, sedangkan Gigasporaceae dominan pada tanah berpasir dan species Glomus memiliki sebaran yang luas sehingga disebut bersifat generalis [18]. Pada penelitian ini digunakan pupuk mikoriza yang mengandung Glomus spp. sebanyak 20 spora per gram.

Menurut [7] genus Glomus mempunyai daya adaptasi yang 
sangat baik pada berbagai kondisi lingkungan dibandingkan dengan beberapa genus CMA lainnya. Peningkatan infeksi mikoriza seiring bertambahnya pupuk mikoriza yang ditambahkan pada tanaman $C$. frutescens maka diduga spora pada media tanam juga akan meningkat. Menurut [19] spora yang dihasilkan oleh cendawan mikoriza arbuskular (CMA) terbentuk di atas eksternatikal hifa yang melewati permukaan akar. Spora mikoriza dapat bekerja efektif jika berasosiasi dengan akar tanaman sehingga mikoriza dapat berkolonisasi dan berkembang secara mutualistik [18].

\section{KESIMPULAN}

Berdasarkan penelitian yang telah dilakukan dapat disimpulkan bahwa pemberian pupuk mikoriza dengan dosisi 6 g sudah mempu menghasilkan pertumbuhan cabai rawit di tanah pasir baik, namun belum dapat menyamai tingkat pertumbuhan cabai rawit yang ditanah di tanah taman, yaitu sekitar $70 \%$ untuk tinggi tanaman.

\section{DAFTAR PUSTAKA}

[1] A. M. Astiko, W., IR. Sastrahidayat, A. Djauhari, "Soil fertility status and soybean [glycine max (l) merr] performance following introduction of indigenous mycorrhiza combined with various nutrient sources into sandy soil," Agrivita, vol. 35, no. 2, 2013.

[2] A. M. Astiko, W., IR. Sastrahidayat, A. Djauhari, "The Role of Indigenous Mycorrhiza in Combination with Cattle Manure in Improving Maize Yield (Zea Mays L) on Sandy Loam of Northern Lombok, Eastern of Indonesia," Trop Soils, vol. 18, no. 1, 2013.

[3] dan A. F. Harlis, P. Murni, "Pengaruh Jenis dan Dosis Cendawan Mikoriza Arbuskular Terhadap Pertumbuhan Cabai (Capsicum annuum L.) Pada Tanah Ultisol," Biospecies, vol. 1, no. 2, 2008.

[4] A. M. Nasihien, Ronny D., I. Dhaniarti, "Portable urban agriculture technology and soil nutrient drive app that support farmers profit," Int. J. Eng. Technol., vol. 7, pp. 331-334, 2008.

[5] D. . Hayman, "The physiology of vesicular-arbuscular endomycorrhizal symbiosis,” J. Bot, vol. 61, pp. 944-963, 1983.
[6] I. M. Nusantara, A.D., Y.H. Bertham, Bekerja Dengan Fungi Mikoriza Arbuskula. Bogor: IPB Press, 2012.

[7] and T. H. Brundrett, M, N Bougher, RW Bell, Working with Mycorrhizas in Forestry and Agriculture. ACIAR, 1996.

[8] D. B. and L. S. Charoenpakdee. S, Phosri. C, "The Mycorrhizal Status Of Indigenous Arbuscular," 2010.

[9] H. S. and S. Razaq, M. P. Zhang, "Influence of nitrogen and phosphorous on the growth and root morphology of Acer mono," PLoS One, 2007.

[10] B. R. Fahmi, A., Syamsudin, SN. Utami, "Pengaruh Interaksi Hara Nitrogen dan Fosfor Terhadap Pertumbuhan Tanaman Jagung (Zea mays L.) pada tanah regosol dan latosol," Berita Biologi, 2010.

[11] A. M. McFarland JW, Ruess RW, Kielland K, Pregitzer K, Hendrick R, "Cross-ecosystem comparisons of in situ plant uptake of amino acid-N and NH4," Ecosystems, vol. 13, pp. 177-193, 2010 .

[12] M. Miransari, "Arbuscular mycorrhizal fungi and nitrogen uptake," Arch Microbiol, vol. 193, pp. 77-81, 2011.

[13] N. A. and N. K. Yeasmin, Tanzima, P. Zaman, A. Rahman, "Arbuscular mycorrhizal fungus inoculum production in rice plants," African J. Agric. Res., vol. 2, no. 9, pp. 463-467, 2007.

[14] A. dan M. Nurbaity, "Efisiensi Penggunaan Air, Benefit dan Cost Tanaman Jagung Bermikoriza yang Mengalami Cekaman Air," in Prosiding Seminar Peran Biotkenologi Dalam Rehabilitasi Lahan Kritis di Tatar Sunda, 2007.

[15] A. W. M. Gunawan, "Makalah pengajaran kursus singkat biologi cendawan," Institut Pertanian Bogor, 1994.

[16] I. R. Sastrahidayat, "Aplikasi tablet Mikoriza pada beberapa jenis tanaman di Jawa Timur. Jurnal Penelitian Ilmu-Ilmu Hayati," Life Sci., vol. 9, no. 1, pp. 8-15, 1997.

[17] A. M. Nurhalimah, S., S. Nurhatika, "Eksplorasi Mikoriza Vesikular Arbuskular (MVA) Indigenous pada Tanah Regosol di Pamekasan, Madura," J. Sains Dan Seni Pomits, vol. 3, no. 1, 2014.

[18] dan W. W. Talanca, A.H., Soenartiningsih, S. Rahamma, "Penggunaan Jamur Mikoriza Vesikular-Arbuskular (MVA) untuk Pengendalian Penyakit Hawar Upih Daun Jagung (Rhizoctonia solani)," Risal. Penelit. Jagung dan Serealia Badan Litbang Pertan., vol. 5, 2011.

[19] A. H. Fitler, "The role and ecological sig-nificance of vesiculararbuscular mycorrhizal in temperature ecosystems and environment," Elseiver Sci. Publ., vol. 29, pp. 137-151, 1989. 